Journal of Biological Sciences 9 (8): 841-850, 2009

ISSN 1727-3048

(C) 2009 Asian Network for Scientific Information

\title{
Bacterial Pollution in Molluses Arch Clam, Orbicularia orbiculata and Blood Cockle, Anadara granosa of Pahang Estuary, Malaysia
}

\author{
${ }^{1}$ K.C.A. Jalal, ${ }^{2}$ M. Najiah, 'M. Fathiyah, 'Y. Kamaruzzaman, 'Mohd Nor Omar, \\ ${ }^{3}$ S.M. Nurul Amin and ${ }^{4}$ Irwandi Jaswir \\ 'Department of Biotechnology, Kulliyyah of Science, International Islamic University Malaysia, \\ Jalan Sultan Ahmad Shah, Bandar Indera Mahkota, 25200, Kuantan Pahang, Malaysia \\ ${ }^{2}$ Department of Fisheries and Aquaculture, Faculty of Agrotechnology and Food Science, \\ University Malaysia Terengganu, 21030 Terengganu, Malaysia \\ ${ }^{3}$ Laboratory of Marine Science and Aquaculture, Institute of Bioscience, \\ University Putra Malaysia, 43400 Serdang, Selangor, Malaysia \\ ${ }^{4}$ Department of Biotechnology Engineering, Kulliyyah of Engineering, \\ International Islamic University, Malaysia
}

\begin{abstract}
A study was conducted on physico-chemical parameters and bacterial pollution in Orbicularia orbiculata (Wood, 1828) and Anadara granosa (L.) at Pahang estuary from January to February 2009 . The temperature was ranged from $28.00-29.87^{\circ} \mathrm{C}, \mathrm{pH} 7.79-8.10$, specific conductivity $51.49-55.89 \mathrm{mS} \mathrm{cm}^{-1}$, salinity 18.74-30.10 ppt., TDS 33.63-39.59 $\mathrm{g} \mathrm{L}^{-1}$, DO 6.80-7.50 $\mathrm{mg} \mathrm{L}^{-1}$. The nitrate concentration was found to be highest at Station $3(14.09 \mu \mathrm{g}$ at $\mathrm{N}-1)$ and lowest at Station $2(7.04 \mu \mathrm{g}$ at $\mathrm{N}-\mathrm{l})$. The nitrite concentration showed highest concentration at Station $4(7.07 \mu \mathrm{g}$ at N-l) and lowest concentration at Station $2(1.67 \mu \mathrm{g}$ at N-1). Whilst the phosphate content was higher $(10.78 \mu \mathrm{g}$ at N-1) at Station 3 and lowest at Station $2(2.34 \mu \mathrm{g}$ at N-1). A total of 60 Orbicularia orbiculata and 40 Anadara granosa samples were subjected to microbiological analysis. The bacteria were isolated using non selective agar such as TSA agar and selective agar before they were identified using conventional methods in combination with API identification kit. A total of nine bacterial species were identified from Orbicularia orbiculata. They were Escherichia coli., Aerococcus viridans 1, Aerococcus viridans 2, Gemella morbillorum, Kocuria varians, Micrococcus sp., Pseudomonas aeruginosa, Staphylococcus sciuri, Streptococcus pneumoniae. Whilst, Nineteen bacterial species were identified in Anadara granosa such as Aeromonas hydrophila group 1, Aerococcus viridians 1, Aerococcus viridans 2, Chromobacterium violaceum., Enterobacter gergoviae, Erwinia sp., Escherichia coli, Enterococcus avium, Gemella morbillorum, Kluyvera sp., Vibrio fluvialis, Vibrio cholerae, Vibrio parahaemolyticus, Lactococcus lactis, Leuconostoc sp., Staphylococcus capitis, Staphylococcus lentus, Staphylococcus epidermidis, Staphylococcus xylosus. The finding indicates that the edible mollusc of Pahang estuary was polluted with pathogenic bacteria which could be harmful for human consumption.
\end{abstract}

Key words: Bacterial pollution, molluscs, pahang estuary, Malaysia

\section{INTRODUCTION}

Bacteria are important components of coastal microbial communities which they plays an important role in nutrient and carbon cycling (Azam et al., 1983; Janina et al., 2008), trophic dynamics of aquatic food webs and in the remineralization of dissolved particulate organic matter and acts as disease agents in human health. The seasonal and spatial abundance, biomass and composition of coastal microbial communities should be much more variable then those of open sea communities, due to the greater variability in factors influencing their growth characteristic of coastal water (Lipp et al., 2001a, b). Environmental parameters do not only influence the size and composition of microbial communities but also the activity and viability of these bacteria. Hence, it is very important to study the distribution of the microbes and try to determine the range of physico-chemical parameters in order to understand the dynamic of microbial communities available in aquatic organism (Jalal et al., 2009). Aquatic animals are nutritionally very important for human consumption, as they are excellent

Corresponding Author: K.C.A. Jalal, Department of Biotechnology, Kulliyyah of Science, International Islamic University Malaysia, Jalan Sultan Ahmad Shah, Bandar Indera Mahkota, 25200, Kuantan Pahang, Malaysia 
sources of proteins, trace elements and polyunsaturated fatty acids (Ruxton et al., 2005). Consequently, there is a global increase in the demand of fish and shellfish products (FAO, 2006). As fisheries cannot provide sufficient amounts of aquatic products to fulfil the consumer needs, aquaculture is the crucial alternative resource. Aquaculture has become more important and intensive over the last decades and is presently the fastest growing food production industry with an average yearly growth rate of more than $6 \%$ over the last 20 years (Brugère and Ridler, 2004). Despite the technological improvements that allowed the expansion of aquaculture over the years, diseases are still a major constraint (FAO, 2006).

Epidemiologists have long known that molluscs are capable of harbouring disease agents significant to human health. The molluscs accomplish this phenomenon by filter feeding, whereby seawater is pumped in through the gills which entrap larger planktonic food organisms within the cilia and mucus of the respiratory epeithelium (Purchon, 1977). As a result these molluscs also take in smaller incidental particles including bacteria and viruses suspended in ambient sea water or adsorbed onto the surfaces of organic and inorganic solids. Consequently, human pathogens including coliform and Vibrio species of bacteria as well as polio and hepatitis viruses have been detected in bivalve species from clean and organically polluted areas (Kempelmacher et al., 1972; Thompson and Vanderzant, 1976). One of the major threats in environmental pollution is the microbial accumulation in the seafood such as shellfish and brackishwater fishes (Knap et al., 2002). Microbiological pollution in shellfish-growing waters is a common problem in almost all the coastal areas of developing countries (Stegeman et al., 2002). Shellfish-borne infectious diseases are generally transmitted through a fecal-oral route (the shellfish become contaminated by sewage and are eaten by humans). The pathway can be quite circuitous. The cycle usually begins with fecal contamination of the growing waters. Feces deposited on land surfaces can release pathogens into surface waters via storm water runoff or collected wastes can be discharged directly into a waterway. The runoff or discharge may go directly into the growing area or indirectly as is the case with wastes transported by freshwater streams to estuarine or marine waters. Information concerning the relationship between sewage pollution of bivalve shellfish growing areas and human disease is available in several good summaries. Seafood is high on the list of foods transmitting disease. The safety hazards in seafood production are listed and discussed. It is pointed out that there are serious safety concerns related to the consumption of raw fish and shellfish due to the presence of biological (bacteria, virus and parasites) and chemical (biotoxins) hazards (Huss et al., 2000).

All bivalve shellfish including gastropods, clams, oysters, cockles, scallops and geoducks are filter feeders that can bio-accumulate any contaminants that may be in the aquatic environment through the process of filtering food from the water column. These contaminants may include human pathogens such as Vibrio cholera, Salmonella typhi, Giardia lamblia, Cryptosporidium parvum and Hepatitis A, which can be spread through the fecal contamination of water. These pathogens can be a risk to human health, even at very low concentrations (Legani et al., 1998). Bivalve shellfish have been used for decades as bioindicators of aquatic contamination with heavy metals and pesticides. In recent years, shellfish have also been recognized worldwide as bioindicators of aquatic contamination with fecal origin bacteria and viruses (Chan, 1995).

Therefore, shellfish in-growing waters must be examined to ensure that pathogenic microorganisms are not present. Moreover, consumption of bivalves harvested from contaminated area can cause illness to human. For instance, Vibrio cholera, Salmonella typhi, Giardia lamblia and Cryptosporidium parvum which can be spread out through the fecal contamination of water. Outbreaks of Cholera, Hepatitis A and Dysenteric shellfish poisoning have been linked to consumption of contaminated cockles (Kanchanapangka et al., 2002). The actual concentration in the tissues is dependent upon the rate at which bivalves pump water through the gills; the concentration and physical characteristics of the microbe in the ambient sea water; and sea water temperature, salinity and turbidity (Liu et al., 1967). Physicochemical parameters are often used as important measurement of water quality as they provide useful information on the status of the water body. The study of physicochemical parameters is also important as these factors determine the distribution and composition of bacterial community (Hahn, 2006) temporarily and spatially within habitat (Lindstrom, 1998; Dominik and Hofle, 2002) as well as between habitats (Yannarell and Triplett, 2004; Wu and Hahn, 2006). The molluscs which have widely been used as bioindicators in Malaysia are Perna viridis, Crassostrea sp., Meretrix sp., Phaxas attenuatus, Haliotis sp., Strombus canarium, Orbicularia orbiculata, Atrina sp., Pteria penguin, Donax sp., Oliva sp. and Anadara granosa (Wang, 1996) .

In Malaysia, Pahang estuary provides good breeding and grow out sites for shell fishes and other commercial fishes. The estuary is driven from Pahang River, which is 
the longest river (approx. $420 \mathrm{~km}$ ) in Peninsular Malaysia and it is connected to South China Sea. Rapid population growth and development in coastal area along Pahang estuary has deteriorated the quality of coastal waters which served as their habitat. Most of the studies conducted at Pahang estuary focusing on fish ecology (Jalal et al., 2008) and chemical pollution the coastal water Pahang (Kamaruzzaman et al., 2002). Urbanization and industrialization of the lower reaches of many estuaries and tributaries have resulted in extensive filling of wetlands and reduce shallow water and riparian habitat. The environment impacts due to dredging and sand mining in Pahang estuary have the potential to change water quality and impact local biota. Besides, it attributed to massive displacement of the substrate and the subsequent destruction of non-motile benthic communities, the indirect impacts resulting from the dredging are more fatal.

Considering the popularity of Orbicularia orbiculata and Anadara granosa of molluscs as edible food in this region, it is important to create awareness to the public on health risks of consuming these molluscs. Based on above perspectives the present study was carried out to determine the bacterial pollution in Orbicularia orbiculata and Anadara granosa at Pahang estuary, Malaysia.

\section{MATERIALS AND METHODS}

Sampling location: Overall 4 potential areas Station 1 (Mouth of the Sea), Station 2 (Sand mining area), Station 3 (Mangrove area), Station 4 (Near freshwater area) were chosen as our sampling stations which covers estuary, brackish water and mangrove areas of Pahang estuary.

Sixty Orbicularia orbiculata and forty Anadara granosa were collected ( $03^{\circ} 33^{\prime} 01.78$ ? E 103 $25^{\circ} 56.48$ ?) from January to February 2009. The average length and weight of Orbicularia orbiculata and Anadara granosa species were $5.5 \mathrm{~cm}, 14 \mathrm{~g}$ and $3.0 \mathrm{~cm}, 5.8 \mathrm{~g}$, respectively. The sampling was conducted once a month at Pahang estuary at the east-coast of Malaysia. The sampling site and seasonal distribution of these molluscs are given in (Fig. 1, Table 1).

Sample collection and microbiological analysis: The samples were collected rinsed and drained at the time of

Table 1: Monthly distribution of Orbicularia orbiculata and Anadara granosa

\begin{tabular}{lllllllll}
\hline & St. 1 & St. 1 & St. 2 & St. 2 & St. 3 & St. 3 & St. 4 & St. 4 \\
Months/09 & AC & BC & AC & BC & AC & BC & AC & BC \\
\hline January & 5 & 3 & 1 & 0 & 10 & 13 & 10 & 8 \\
February & 3 & 1 & 0 & 0 & 17 & 11 & 14 & 4 \\
\hline
\end{tabular}

Arch Clam (AC), Orbicularia orbiculata and Blood Cockle (BC), Anadara granosa

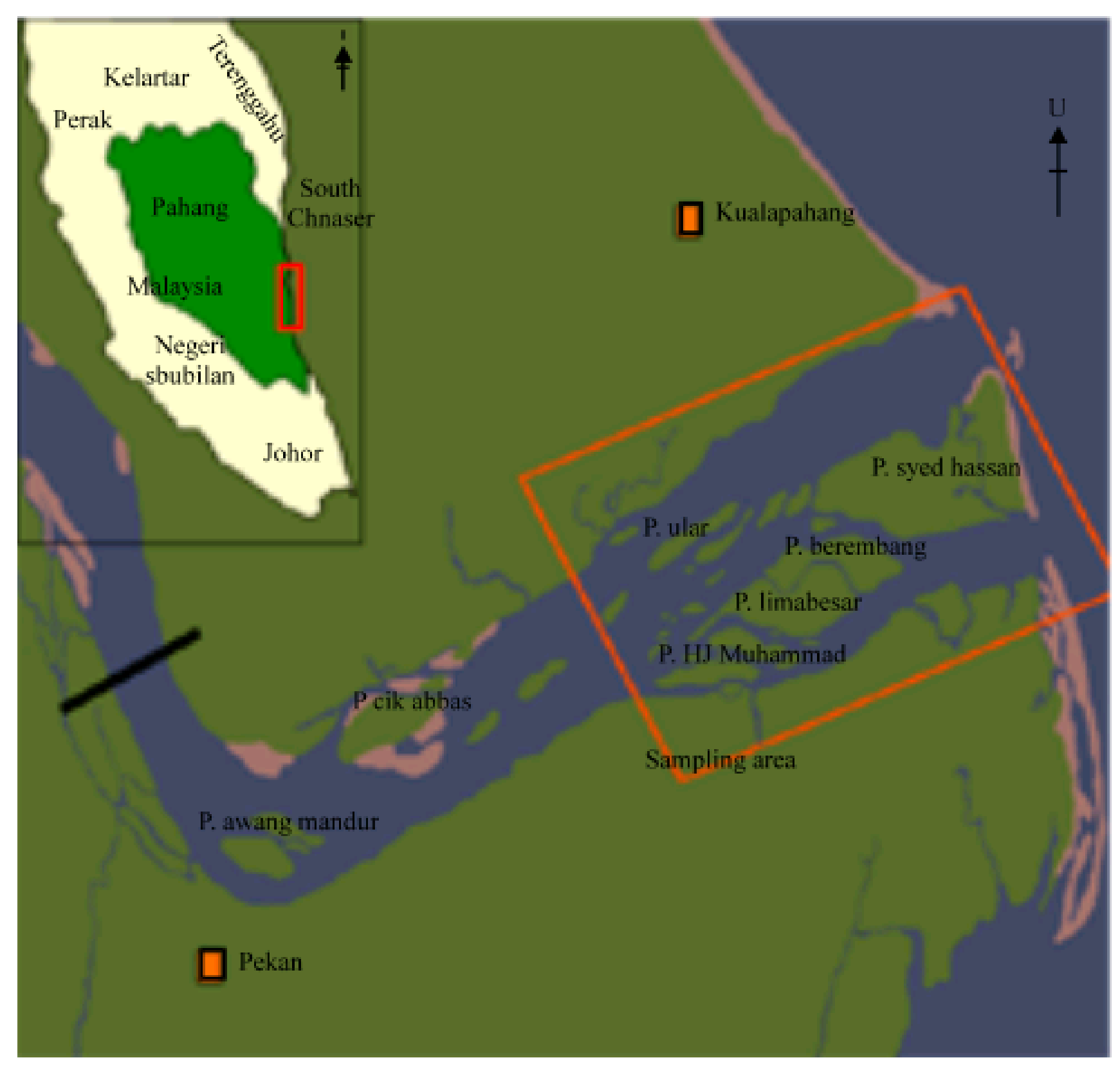

Fig. 1: Sampling site (Pahang estuary), (N $03^{\circ} 33^{\prime} 01.78^{\prime \prime}$ E $\left.103^{\circ} 25^{\prime} 56.48^{\prime \prime}\right)$ 
sampling. The samples were then directly placed in plastic bag, properly packed in a cool box and transported to Microbiology Laboratory, Faculty of Science and International Islamic University Malaysia Kuantan within an hour. During transportation the temperature of ice box was maintained at $4^{\circ} \mathrm{C}$. At the laboratory, the shell of mollusks Orbicularia orbiculata and Anadara granosa were washed and scrubbed under running tap water and their surface were sterilized by rinsing in $70 \%$ ethanol. Then they were opened aseptically with a flame sterilized shucking knife. The experiment was conducted on total flesh only instead of different tissues. The flesh was weighed before transferring each individual sample to a sterile physiological saline and crushed with a stomacher. They were immediately cultured onto universal agar Trypticase Soy Agar (TSA) and selective agars such as Thiosulfate Citrate Bile Salt Sucrose (TCBS), Pseudomonas Aeromonas Selective Agar Base (GSP), Deoxycholate Hydrogen Sulfide Lactose (DHL), Mac Conkey, Eosin Methylene Blue (EMB), Baird Parker and Bromothymol blue lactose cystine (Brolacin) (Merck, Germany). They were incubated for 24 to $48 \mathrm{~h}$ at $30^{\circ} \mathrm{C}$. Then, five colonies which represent different morphologies per plate were selected from each sample and restreaked three times onto nutrient agar plates to ensure pure bacterial culture. Phenotypical characteristics, Gram staining and oxidase production were determined for all isolates according to APHA (1970), Holt et al. (1994), Whitman (2004) and Najiah et al. (2008). Further identification was carried out using a commercial Identification System kit (API) following manufacturers instruction. The identified bacteria were also streaked onto blood agar to determine the hemolytic ability.

Physico-chemical parameters: In any water body, the knowledge of physico-chemical parameters is an essential requirement for the sustainable development and management of aquatic resources. Thus the physicochemical parameters: temperature, $\mathrm{pH}$, dissolved oxygen, total dissolved solids, conductivity, nitrate, nitrite and phosphate of the sampling areas were measured by using 'Hydro lab' Datasonde 4a, USA. All the data were recorded in-situ and later analyzed in the laboratory. All the parameters were followed as described by Parsons et al. (1992).

\section{RESULTS AND DISCUSSION}

The physico-chemical parameters which include temperature $\left(28.00-29.10^{\circ} \mathrm{C}\right)$, DO $\left(6.80-7.50 \mathrm{mg} \mathrm{L}^{-1}\right)$, pH (7.79-8.10), salinity (18.74-30.10 ppt), TDS (33.63-39.59 $\mathrm{g} \mathrm{L} \mathrm{L}^{-1}$ ) and specific conductivity (51.49-55.89 $\mathrm{mS} \mathrm{cm}^{-1}$ ) are described in Table 2. The results showed that there are no significant variations on physico-chemical parameters of water among the four different stations. It indicates that the Pahang estuarine waters are well mixed. This supports the findings of the coastal water of Langkawi (Jalal et al., 2009). Similarly it was found that there were no significant differences on physic-chemical parameters among the coastal waters Portdickson and Malacca (Law et al., 2002). While the dissolved inorganic nutrients showed significant differences of Nitrate, Nitrite and Phosphate among the stations are shown in Table 3. In fact station 3 (14.09 $\mu \mathrm{g}$ at $\mathrm{N}-1)$ and station $4(11.10 \mu \mathrm{g}$ at $\mathrm{N}-1)$ were showed the highest amount of nitrates than those of stations $1(9.18 \mu \mathrm{g}$ at $\mathrm{N}-1)$ and station $2(7.04 \mu \mathrm{g}$ at $\mathrm{N}-1)$. Similarly the concentration of phosphate was higher at station 3 and $4(10.78$ and $7.04 \mu \mathrm{g}$ at $\mathrm{N}-1)$ than those of stations 1 and $2(5.52$ and $2.34 \mu \mathrm{g}$ at $\mathrm{N}-1)$. This is also agreed with the findings of other studies in the estuarine water of Malaysia (Kamaruzzaman et al., 2002, 2004). During this study stations 3, 4 was shown higher amount of nutrients. This is probably due to its surrounding area comprises mangroves flora and fauna and fresh water inputs near the river mouth. The products of anaerobic and aerobic leaf litter decomposition in the mangrove sediment provided the bulk of inorganic and organic matter in the tidal creek which was observed during our study along the Pulau Tuba areas. Similar consequences have been found by Khalik et al. (1997). According to him the net export of these degradation products from the mangrove was about $20 \%$ of total litter fall. The higher rate of organic carbon near the mangrove station may be due to the coastal outwelling of organic carbon from mangrove wetlands. Despite this clear allochthonous organic matter source fueling microbial respiration, indicated that autochthonous productivity was an important supplementary carbon source, perhaps fueling higher trophic levels. The increase rates of nutrients at the station- 4 might be due to the influx of anthropogenic

Table 2: Water quality parameters at four stations of Pahang Estuary

\begin{tabular}{|c|c|c|c|c|c|c|}
\hline Stations & Temp. $\left({ }^{\circ} \mathrm{C}\right)$ & $\mathrm{pH}$ & Sp. conduc $\left(\mathrm{mS} \mathrm{cm}^{-1}\right)$ & Salinity (ppt) & $\operatorname{TDS}\left(\mathrm{g} \mathrm{L}^{-1}\right)$ & $\mathrm{DO}\left(\mathrm{mg} \mathrm{L}^{-1}\right)$ \\
\hline 1 & $29.87 \pm 0.02^{a}$ & $8.00 \pm 0.01^{\mathrm{t}}$ & $53.67 \pm 0.08^{a}$ & $30.10 \pm 0.15^{a}$ & $35.60 \pm 0.05^{\mathrm{a}}$ & $6.80 \pm 0.10^{2}$ \\
\hline 2 & $28.89 \pm 0.05^{a}$ & $8.05 \pm 0.04^{\mathrm{a}}$ & $51.49 \pm 0.10^{2}$ & $28.10 \pm 0.07^{a}$ & $33.63 \pm 0.06^{\mathrm{a}}$ & $7.00 \pm 0.05^{a}$ \\
\hline 3 & $28.00 \pm 0.0^{2}$ & $7.79 \pm 0.03^{\mathrm{a}}$ & $55.89 \pm 0.03^{\mathrm{a}}$ & $23.80 \pm 0.06^{a}$ & $35.73 \pm 0.15^{\mathrm{a}}$ & $6.89 \pm 0.06^{2}$ \\
\hline 4 & $29.10 \pm 0.04^{a}$ & $8.10 \pm 0.03^{z}$ & $54.08 \pm 0.07^{a}$ & $18.74 \pm 0.05^{a}$ & $39.59 \pm 0.16^{\mathrm{a}}$ & $7.50 \pm 0.04^{2}$ \\
\hline
\end{tabular}

Data are expressed as Mean \pm SE. Values in each column having different superscript are not significantly different $(p>0,05$ ) 
Table 3: Trends of nutrients at four stations of pahang estuary

\begin{tabular}{lllr}
\hline & Nitrate $\left(\mathrm{NO}_{3}^{-}\right)$ & Nitrite $\left(\mathrm{NO}_{2}^{-}\right)$ & Phosphate $\left(\mathrm{PO}_{4}^{3-}\right)$ \\
\cline { 2 - 4 } Stations & $9.18 \pm 0.50^{\mathrm{a}}$ & $3.89 \pm 0.07^{\mathrm{b}}$ & $5.52 \pm 0.02^{4}$ \\
\hline 1 & $7.04 \pm 1.06^{2}$ & $1.67 \pm 0.02^{\mathrm{a}}$ & $2.34 \pm 0.01^{2}$ \\
3 & $14.09 \pm 0.10^{\mathrm{b}}$ & $4.07 \pm 0.10^{\mathrm{b}}$ & $10.78 \pm 0.03^{\mathrm{b}}$ \\
4 & $11.10 \pm 0.07^{\mathrm{b}}$ & $7.10 \pm 0.04^{\mathrm{b}}$ & $7.04 \pm 0.05^{\mathrm{b}}$ \\
\hline
\end{tabular}

Data are expressed as Mean $\pm S E$. Values in each column having the different superscripts are significantly different $(\mathrm{p}<0.05)$

Table 4: Colony forming unit (cfu $\mathrm{mL}^{-1}$ ) of different agar plates for Anadara granosa

Colony forming unit ( $\mathrm{cfu} \mathrm{mL}^{-1}$ ) on agar plate

\begin{tabular}{lllll} 
Dilutions & TSA & MC & EMB & BP \\
\hline Pure & TNTC & TNTC & TNTC & TNTC \\
$10^{1}$ & TNTC & TNTC & 3,100 & 2,750 \\
$10^{2}$ & TNTC & TNTC & 7,500 & 6,000 \\
$10^{3}$ & TNTC & TNTC & 50,000 & 15,000 \\
\hline
\end{tabular}

Too Numerous To Count (TNTC)

Table 5: Colony forming unit (cfu $\mathrm{mL}^{-1}$ ) of different agar plates for Orbicularia orbiculata

Colony forming unit $\left(\mathrm{cfu} \mathrm{mL}^{-1}\right)$ on agar plate

\begin{tabular}{lllll} 
Dilutions & TSA & MC & EMB & BP \\
\hline Pure & TNTC & TNTC & TNTC & TNTC \\
$10^{1}$ & TNTC & TNTC & TNTC & TNTC \\
$10^{2}$ & TNTC & TNTC & TNTC & TNTC \\
$10^{3}$ & 560,000 & 400,000 & 500,000 & 365,000 \\
\hline
\end{tabular}

inputs and waste discharges containing nitrogen and phosphorous compounds from river runoff to the environments. A similar finding has been reported by other researchers in their studies (McLusky and Elliot, 2004; Law et al., 2002). These nutritional factors perhaps might be the vital factors for the growing of bacterial population in the molluscs of Pahang estuary. As such the study showed that highest populations of molluscs (Arch clam, Orbicularia orbiculata and Blood Cockle, Anadara granosa) were available at station 3 and station 4 due to high contents of nutrients.

Bacterial isolation and identification: All agar plates (TSA, MC, EMB and BP) were observed under colony counter and the numbers of colonies were recorded. The colony forming unit (cfu) was calculated from the dilution as described in Table 4 and 5. In total 228 isolates were obtained from 100 molluscs representing 24 different bacteria species. The study showed that Escherchia coli (30 isolates), was the most frequently isolated bacteria from the oyster tissue followed by Streptococcus pneumonia (22 isolates), Vibrio cholerae (19 isolates), Vibrio parahaemolyticus (19 isolates), Vibrio parahaemolyticus (17 isolates), Aeromonas hydrophila (15 isolates), Gemella morbillorum (15 isolates), Chromobacterium violaceum (12 isolates), Aerococcus viridians (10 isolates), Pseudomonas aeruginosa (10 isolates), Enterobacter gergoviae (8 isolates),
Table 6: Types of bacteria in Orbicularia orbiculata and Anadara granosa Orbicularia orbiculata

\begin{tabular}{ll} 
Anadara granosa $(\mathrm{L})$. & (Wood, 1828) \\
\hline Aeromonas hydrophila group 1 & Aerococcus viridans
\end{tabular}

( $\beta$-hemolysis)

Aerococcus viridans 2

( $\beta$-hemolysis)

Gemella morbillorum

( $\beta$-hemolysis)

Pseudomonas aeruginosa

Streptococcus pneumonia

Staphylococcus sciuri

( $\beta$-hemolysis)

Kocuria varians

Micrococcus sp

Escherchia coli

Escherchia coli

Gemella morbillorum ( $\beta$-hemolysis)

Kluyvera sp.

Leuconostoc sp. ( $\beta$-hemolysis)

Lactococcus lactis

Staphylococcus capitis

Staphylococcus lentus ( $\beta$-hemolysis)

Staphylococcus epidermidis

Staphylococcus xylosus

Vibrio fluvialis

Vibrio cholerae

Vibrio parahaemolyticus ( $\beta$-hemolysis)

Erwinia sp. (7 isolates), Staphylococcus lentus (7 isolates), Staphylococcus sciuri (5 isolates), Enterococcus avium (4 isolates), Kocuria varians (4 isolates), Staphylococcus capitis (4 isolates), Staphylococcus epidermidis (4 isolates), Staphylococcus xylosus (3 isolates), Vibrio fluvialis (3 isolates), Micrococcus sp. (3 isolates), Kluyvera sp. (3 isolates), Lactococcus lactis (2 isolates) and Leuconostoc sp. ( 2 isolates). Out of 24 bacteria species isolated, only 6 species have the ability to hemolyse blood agar ( $\beta$-hemolysis) which were Aerococcus viridians, Vibrio parahemolyticus, Staphylococcus lentus, Gemella morbillorum, Staphylococcus sciuri and Leuconostoc sp. (Table 6). The result showed 9 species of bacteria were identified in Orbicularia orbiculata and 19 species of bacteria in Andara granosa were identified. The study revealed that Orbicularia orbiculata and Anadara granosa harbour a lot of pathogenic microorganisms including Escherichia coli that pose serious health risks to human. The recovery of human pathogenic bacteria from shellfish samples has been widely reported and most of the studies have focused on fecal contamination, enteric pathogens and pathogenic species of Vibrio (Chan, 1995). Kueh and Chan (1985) compared the microbiota of several species of bivalve molluscs, including oysters (Crassostrea gigas), to that of the surrounding sea water and found differences in both numbers and generic composition. The most frequently detected microorganisms from shellfish were mainly Pseudomonas, but also Vibrio, Acinetobacter and Aeromonas, whereas coliform and coryneform bacteria were the predominant microorganisms from seawater (Kueh and Chan, 1985). 
The results of the present study agree to some extent with other studies as mentioned above. As such we found that Vibrio, Pseudomonas and Aeromonas were present in both molluscs. Prieur et al. (1990) analyzed the microbiota of several bivalve molluscs in an experimental hatchery, including oysters ( $C$. gigas), at different stages of culture. Gram-negative fermentative bacteria corresponding to Photobacterium and Vibrio were more abundant in the ground whole flesh than in the surrounding water. These authors suggested a relationship between the microbiota associated with the mollusc and that of the surrounding sea water. In addition, the bacteria isolated from molluscs were also characterized by a significant proportion of proteolytic and lipolytic strains. Seawater samples were much more diverse that oyster samples and allowed the detection of large numbers of readily cultured heterotrophic bacteria representing new taxa. As such Leuconostoc sp. could be first time reported infected the molluscs of this region. According to Chen (1995) when pollutants are present in the water, they can be concentrated in the shellfish tissues and make the shellfish unsafe to eat. However, these pathogens do not harm the shellfish but can cause illness in humans. Some studies reported that in general, the level of bacterial contamination of shellfish depends on the extent of pollution in the growing waters (Adebayo-Tayo et al., 2006). It is pointed out that there are serious safety concerns related to the consumption of raw fish and shellfish due to the presence of biological (bacteria, virus and parasites) and chemical (biotoxins) hazards (Huss et al., 2000; Janina and Liongina, 2002). Montilla et al. (1995) mentioned the occasional presence of $V$. parahaemolyticus in the bivalves. Interestingly bacteria found in these molluscs especially Vibrio parahaemolyticus was capable of breaking down the red blood cells ( $\beta$-hemolysis) in blood agar without any disease symptoms detected on the molluscs themselves. So far-previous research on pathogenic microorganisms isolated from shell fish and a high abundance of E.coli and vibrios detected in tissues and organs of abalones, bivalves, corals, fish, shrimp, sponges, squid and zooplankton (Najiah et al., 2008). In our study, four species of Vibrios such as $V$. parahaemolyticus, $V$. fluvialis, V. alginolyticus and $V$. cholerae were found in molluscs tissues. The natural bacterial flora of shellfish along the coast of Virginia was investigated by Crasby et al. (1997). Preliminary results showed that the predominant genera were Pseudomonas, Alteromonas, Alcaligenes, followed by Vibrio and Micrococcus. Cytophaga, Flavobacterium, Acinetobacter was less abundant. The generic composition of the natural microflora in the digestive tract of marine molluscs was reported to contain Vibrio and Pseudomonas as dominant groups. A microbiological study on the flora of mussel Mytilus galloprovincialis cultured in Tortch Lagoon, South-East Sardinia, Italy (Salati et al., 1999). The major aerobic bacteria found in the microflora of the mussels belonged to Vibrio/Aeromonas, Actinobacillus/ Aeromonas, Pseudomonas and Bacillus groups. Few Escherichia coli and the absence of pathogens such as Salmonella sp. and Vibrio parahaemolyticus testify to a low degree of fecal contamination of the area (Salati et al., 1999). Consequently, human pathogens including coliform and Vibrio species of bacteria as well as polio and hepatitis viruses have been detected in bivalve species from clean and organically polluted waters of Chesapeake Bay. Disease outbreaks caused by some of these agents have occurred in the human populace following ingestion of poorly cooked or raw shellfish from contaminated area (Lovelace et al., 1968; Kampelmacher et al., 1972; Thompson and Vanderzant, 1976; Lipp et al., 2001a,b). Bacterial pollution was also studied on the mussels in the Upper Gulf of Thailand (Dato-Cajegas and Lin, 1996). Serious contamination with bacteria in those estuaries usually occurred during the rainy season (July-October) and at low tides. Arzul et al. (2001) successfully demonstrated the interspecific transmission of the herpeslike virus, by infecting axenic larvae of $C$. gigas and Crassostrea angulata with virus obtained from the clam Ruditapes philippinarum and from C. gigas. These results confirm that concomitant mortalities in the larvae of several bivalve species may occur in private hatcheries and are promoted by intensive rearing conditions. The cross-contamination of herpes-like virus diseases may also occur between bivalves cultured in hatcheries and natural populations (Hill and Way, 1995). Several reports (Meyers, 1979) describe the in vitro isolation of birnaviruses and reoviruses from bivalve molluscs and attempts to experimentally infect molluscs with the isolates (Bachère, 2003). Guillard (1959) carried out preliminary studies regarding mollusc-microbe interactions. This author demonstrated that two bacterial strains (Vibrio sp. and Pseudomonas sp.) isolated from an infected hard clam (Venus mercenaria) larva were strong pathogens to healthy larvae cultured in germ-free conditions, while germ-free larvae exposed to those bacteria and simultaneously treated with antibiotics were as healthy as the controls. In a second set of experiments, this author showed that axenic larvae exposed to the culture medium of virulent bacteria (previously filtered or heated to remove all bacterial cells) were able to survive, although presenting a delay in growth. Therefore, it seems that live bacteria and not the bacterial metabolites present in the culture medium, are essential to damage clam larvae. 
Some studies have been conducted in the coastal waters of Malaysia (Wang, 1996; Wan Norhana et al., 2007; Roslinda et al., 2004; Najiah et al., 2008). 137 strains were obtained from oyster Crassostrea iredalei representing seven different bacteria species in the Setiu Wetland (Najiah, et al., 2008). Interestingly, some bacteria such Vibrio parahaemolyticus and Leuconostoc sp. were found in Anadara granosa. This study was able to break down red blood cell ( $\beta$-hemolysis) without any disease symptom detected on the shellfish themselves. However, these bacteria could be pathogenic and involve in disease transmission to human. Leuconostoc sp. which can cause severe infection in human has been previously reported (John and Richard, 1993) in other developed countries. So far this is the first time of the findings of Leuconostoc sp. which we found in this region which infected shell fish of Pahang estuary, Malaysia.

In recent years, there has been considerable interest in studying the occurrence and distribution of the various bacterial pollution indicators in the water and associated environment. Microbiological pollution in shellfishgrowing waters is a very common problem in all the coastal areas of developed and developing countries. It has been suggested repeatedly that the bacterial flora of shellfish might reflect the bacteriological conditions of the water and thus be a potential indicator of pollution. Organisms of the coliform and streptococcal groups have been isolated from various species of freshwater shellfish collected in relatively to moderately polluted water in India, Norway, Canada, United States, Margolis also reported that the bacterial flora of freshwater shellfish depends solely upon the shellfish's recent intake of food and the degree of contamination in the food and water. Pollution derived from human activities may cause the potential loss of the natural shell fish resource areas for shell fish harvesting. Perhaps the potential risk of disease transmission could be due to the consumption of raw or lightly cooked fish (Roslinda et al., 2004). A comparative study has been done on faecal coliform and E. coli bacterial counts in shell fish harvested in pre and post-Tsunami from Kedah, Penang in Malaysia. The higher counts of faecal coliform compared to E. coli in almost all shellfish samples examined and inconsistent trend of counts suggest that faecal pollution in these particular shell fish waters might originate from various no-point sources of faecal pollution rather than direct discharge of continuous seepage from leaked waste water or sanitation system which might be due to tsunami.

However, high E.coli counts in carpet clams collected from Kuala Kedah in April, 2005 suggests that the faecal contamination might originate from human origin (Wan Norhana et al., 2006). Meanwhile high FC counts in freshly harvested cockles from Seberang Perai,
Penang had been reported previously (Wang, 1996) thus explain that effluents from heavily populated rivers and drainage from many livestock farms might contribute to the high counts of coliform bacteria in the shell fishes of these areas. Generally, food sources for shellfish include phytoplankton, suspended detritus material and resuspended benthic algae. The balance of these changes from estuary to estuary (Heip et al., 1995; Underwood and Kromkamp, 1999). High turbidity sometimes limits phytoplankton activity and resuspended benthic algal production and detrital carbon and nitrogen will be the major sources of nutrition (Thornton et al., 2002). Benthic material can be suspended on the flooding and ebbing tides as well as moved through bed load transport. Both mechanisms provide food materials for benthic suspension and deposit feeders and routes of entry of pathogenic markers into shell fish. The shell fisheries themselves can have both positive an negative feedbacks on estuarine functioning (carbon flow, sediment characteristics and dynamics) and different exposure routes to faecal contamination and these effects will depend on stocking density and the species farmed (De Jonge and van Beusekom, 1995).

In Malaysia, the area along the estuarine area has been heavily impacted by discharges from municipal and industrial outflows. Since the molluscs are found in water bodies of Pahang estuary containing untreated human and industrial waste, there is a tendency that they may concentrate and accumulate high level of bacterial pathogens which can pose a significant health hazard to consumers. This was due to the rapid development of the area via expansion of the industrialization area as well as the increase in population and this may indirectly affected the aquatic organisms. The environment impacts due to dredging and sand mining induced suspensions have the potential to change water quality and impact local biota. Moreover, non-point source pollution in Pahang estuary has been largely overlooked in the past because it is not as conspicuous in its sources and effects. Non-point source pollution is the result of land use changes and inadequate urban and agricultural storm water management practices. In fact improper land use management practices can result in increased sediment, nutrient, organic-chemical and heavy-metal loadings to streams, while creating abnormal flow rate (Kennish, 2000).

\section{CONCLUSIONS}

Marine shell fish especially bivalve molluscs are unavoidable in estuarine and salt waters which may be used in the rearing of anadromous fishes or which may be directly downstream of freshwater egg and fry facilities 
operating on short watersheds. The established occurrence of certain viral finfish pathogens in common species of marine bivalve mollusks indicates that shellfish could introduce exotic finfish diseases when transported to other waters for commercial or experimental purposes from areas where such agents may be endemic. The study indicates that Orbicularia orbiculata and Anadara granosa from Pahang estuary contained various pathogenic bacteria to human. In addition to that, some of these bacteria possessed, the ability to hemolyse blood could indicate the presence of some virulence factors. So, continuous monitoring on bacterial pollution in Molluscs at Pahang estuary should be done frequently by the concern authorities to ensure these mollusks are suitable for human consumption. Consequently, if certification procedures are exercised for shellfish pathogens, some additional effort made in screening molluse tissues for incidental viral finfish pathogens would provide significant protection against the introduction of these agents by movement of shellfish.

\section{ACKNOWLEDGMENT}

This study was an offshoot of the estuarine research activities in Pahang, East Coast of Malaysia funded by Research Management Centre, International Islamic University Malaysia.

\section{REFERENCES}

Adebayo-Tayo B.C., A.A. Onilude, A.A. Ongujobi and D.O. Adejoye, 2006. Bacteriological and proximate analysis of periwinkles from two different creeks in Nigeria. World Applied Sci. J., 1: 87-91.

Arzul, I., T. Renault and C. Lipart, 2001. Experimental herpes-like viral infections in marine bivalves: Demonstration of interspecies transmission. Dis. Aquat. Organ., 46: 1-6.

APHA, 1970. Procedures for the Bacteriological Examination of sea Water and Shellfish. American Public Health Association, Washington, USA.

Azam, F., T. Fenchel, J.G. Field, J.S. Gray, L.A. Meyer-Reil and F. Thingstad, 1983. The ecological role of water column microbes in the sea. Mar. Ecol. Prog. Ser., 10: 257-263.

Bachère, E., 2003. Anti-infectious immune effectors in marine invertebrates: Potential tools for disease control in larviculture. Aquaculture, 227: 427-438.

Brugere, C. and N. Ridler, 2004. Global Aquaculture Outlook in the Next Decades: An Analysis of National Aquaculture. FAO., Rome.

Chan, T.Y.K., 1995. Shellfish borne illnesses: A Hong Kong perspective. Trop. Geographic Med., 47: 305-307.
Chen, H.C., 1995. Seafood microorganisms and seafood safety. J. Food Drug Anal., 3: 133-144.

Crasby, M.A., J. Boettcher and B.J. Barber, 1997. Development of rapid identification system to study the natural flora of the oyster Crassostrea virginica. J. Shellfish Res., 16: 334-335.

Dato-Cajegas, C.R.S. and C.K. Lin, 1996. Water quality, bacterial counts and mussel growth in four mussel culture areas in the upper Gulf of Thailand. Asian Sci., 9: 221-230.

De-Jonge, V.N. and J.E.E. van Beusekom, 1995. Resuspension of sediment microphytobenthos from the tidal flats in the EMS Estuary. Limnol. Oceanogr., 40: 766-778.

Dominik, K. and M.G. Hofle, 2002. Changes in bacterioplankton community structure and activity with depth in a eutrophic lake as revealed by $5 \mathrm{~S}$ rRNA analysis. Applied Environ. Microbiol., 68: 3606-3613.

FAO, 2006. The State of World Fisheries and Aquaculture. FAO, Rome, Italy.

Guillard, R., 1959. Further evidence of the destruction of bivalve larvae by bacteria. Biol. Bull., 55: 260-282.

Hahn, M.W., 2006. The microbial diversity of inland water. Curr. Opin. Biotechnol., 17: 256-261.

Heip, C.H.R., N.K. Goosen, P.M.J. Herman, J. Kromkamp, J.J. Middleburg, and K. Soetaert, 1995. Production and consumption of biological particles in temperate tidal estuaries. Oceanogr. Mar. Biol. Ann. Rev., 33: 1-149.

Hill, B.J. and K. Way, 1995. Serological classification of infectious pancreatic necrosis (IPN) virus and other aquatic birnaviruses. Ann. Rev. Fish. Dis., 5: 55-75.

Holt, J.G., N.R. Krieg, P.H. Sneath, J.J. Stanley and S.T. Williams, 1994. Bergey's Manual of Determinative Bacteriology. Williams and Wilkins, Baltimere, USA.

Huss, H.H., A. Reilly and P.K.B. Embarek, 2000. Prevention and control of hazards in seafood. Food Control, 11: 149-156.

Jalal, K.C.A., A.M. Azfar, B.Y. Kamaruzzan and S. Shahbudin, 2008. Fish assemblages in sand mining areas of pahang estuary, Malaysia. Proceedings of International Conference: The South China Sea: Sustaining Ocean Productivities Maritime Communities and the Climate, Nov. 25-30, University of Malaya, Malaysia, pp: 10-15.

Jalal, K.C.A., M.S. Zahir, N. Faizul, H.N. Kamaruzzaman, B.Y.R. Hashim and S. Shahbudin, 2009. Spatial distribution of bacterial communities in Kilim river Langkawi, Malaysia. Proceedings of International Conference on Marine Ecosystem, (ICME'09), INCOMES, Langkawi Island, Malaysia, pp: 7-7. 
Janina, D. and M. Liongina, 2002. Change in the intestinal microflora of molluscs from the Neris river depending on pollution. Acta Zool. Lituanica, 12: 76-81.

Janina, Š., L. Mickënienë and J. Baršienë, 2008. Bacteria in the digestive system of mollusks from lithuanian lakes. Ekologija, 54: 271-277.

John, A. and R.F. Richard, 1993. Identification of leuconostoc sp. by analysis of soluble whole-cell protein pattern. J. Clin. Microbiol., 31: 1030-1033.

Kamaruzzaman, B.Y., Y. Rosnan, H. Mohd Lokman, N.A.M. Shazili and A. Nor-Antonina, 2002. Physicochemical characteristics and dissolved trace metals in the chukai river estuary, terengganu, Malaysia. Chem. Res. Commun., 25: 41-51.

Kamaruzzaman, Y., M.C. Ong and K.Y.S. Willison, 2004. Trace metal concentration in the surface sediments of Paka mangrove forest, Terengganu, Malaysia. Malaysian J. Sci., 23: 55-60.

Kampelmacher, E.H., L.M. van Noorl, D.A. Mossel and F.J. Groen, 1972. A survey of the occurrence of Vibrio parahaemlyticus and V. Aginoyticus on mussels and oysters and in estuarine waters in the Netherlands. J. Applied Bacteriol., 35: 431-438.

Kanchanapangka, S., M. Sarikaputi, R. Rattanaphani and K. Poonsuk, 2002. Cockle (Anadara granosa) red blood cell: Structure, histochemical and physical properties. pp: 2545-2546. http://lib.vet.chula.ac.th /Data_files/ebook/Research/CD_Research/80.pdf.

Kennish, M.J., 1997. Practical Handbook of Estuarine and Marine Pollution. Vol. 10, CRC Press, Boca Raton, ISBN: 9780849384240, pp: 1-524.

Khalik, A., H.J. Wood, Z. Ahmad, N. Azhar, M.D. Shazili, R. Yaakob and R. Carpenter, 1997. Geochemistry of sediments in Johor Strait between Malaysia and Singapore. Continental Shelf Res., 17: 1207-1228.

Knap, A., E. Dewailly and C. Furgal, 2002. Indicators of ocean health and human health: A research framework. Environ. Health Perspectives, 110: 839-845.

Kueh, C.S.W. and K.Y. Chan, 1985. Bacteria in bivalve shellfish with special reference to the oyster. J. Applied Bacteriol., 59: 41-47.

Law, A.T., Y.S. Hii, K.J. Jong and M.L. Mok, 2002. JICA/UPM Malacca straits expedition No. 4: Petroleum hydrocarbon, nitrogen and phosphoris distribution. Proceedings of the 2nd International Conference on the Straits of Malacca, Oct. 15-18, Penang, Malaysia.

Legani, P., E. Leoni, R. Lev, R. Rossi, G.C. Villa and P. Bisbini, 1998. Distribution of indicator bacteria and bacteriophages in shell fish and shell fish growing waters. J. Appied Microbiol., 85: 790-798.
Lindstrom, E.S., 2001. Investigating influential factors on bacterioplankton community composition: Results from a field study of five mesotrophic lakes. Microbiol. Ecol., 42: 598-605.

Lipp, E.K., K. Kurz, R. Vincent, C. Rodriguez, S.R. Farrah and J.B. Rose. 2001a. The Effects of seasonal variability and weather on microbial fecal pollution and enteric pathogens in a subtropical estuary. Estuaries, 24: 266-276.

Lipp, E.K., S.A. Farrah and J.B. Rose, 2001b. Assessment and impact of microbial fecal pollution and human enteric pathogens in a costal community. Marine Poll. Bull., 42: 286-293.

Liu, O.C., H.R. Seraichekas and B.L. Murphy, 1967. Viral depuration of the northern quahaug. Applied Microbiol., 15: 307-315.

Lovelace, T.E., H. Tubiash and R.R. Colwell, 1968. Quantitative and qualitative commensal bacterial flora of Crassostrea virginica in Chesapeake Bay. Proc. Natl. Shellfish. Assoc., 58: 82-82.

McLusky, D.S. and M. Elliot, 2004. The Estuarine Ecosystems: Ecology, Threats and Management. Oxford University Press, Oxford.

Meyers, T.R., 1979. A reo-like virus isolated from juvenile American oysters (Crassostrea virginica). J. Gen. Virol., 43: 203-212.

Meyers, T.R., 1984. Marine bivalve mollusks as reservoirs of viral fin fish pathogens: Significance to marine and anadromous fin fish aquaculture. Mar. Fish. Rev., 46: 14-17.

Montilla, R., J. Palomer, M.C. Fuster and V. Viñas, 1995. Taxonomy and protein fingerprinting of halophilic Vibrio isolates from bivalves of the Ebre delta. Can. J. Microbiol., 41: 64-69.

Najiah, M.M., K.L. Nadirah, S.W. Lee, W. Wendy, H.H. Ruhil and F.A. Nurul, 2008. Bacteria flora and heavy metal in cultivated oysters Crassostrea iredalei of setiu wetland, East Coast Peninsular Malaysia. Vet. Res. Commun., 32: 377-381.

Parsons, R.P., Y. Maita and C.M. Lalli, 1992. A Manual of Chemical and Biological Methods for Seawater Analysis. Pergamon Press, Oxford.

Prieur, D., G. Mvel, J.L. Nicolas, A. Plusquellec and M. Vigneulle, 1990. Interactions between bivalve molluscs and bacteria in the marine environment. Oceanogr. Mar. Biol. Ann. Rev., 28: 277-352.

Purchon, R.D., 1977. The Biology of the Molluscs. 2nd Edn., Pergamon Press, Oxford, pp: 596.

Roslinda, I., I.A. Ghani, S.M. Ramli and S.A. Azizi, 2004. Comparisons of bacterial loads in green-lipped mussels perna viridis. 3rd Intl. Annual Seminar on Sustainability Science and Management, 4-5 May. 
Ruxton, C., P. Calder, S. Reed and M. Simpson, 2005. The impact of long-chain $\mathrm{n}-3$ polyunsaturated fatty acids on human health. Nutr. Res. Rev., 18: 113-129.

Salati, F.A., E. Meloni and R. Kusuda, 1999. Microbiological study on the flora of mussel Mytilus galloprovincialis cultured in Tortch Lagoon, South-East Sardinia, Italy. Fish. Sci., 65: 657-658.

Stegeman, J.J., A.R. Solow and T.J. Goehl, 2002. Environmental health and the coastal zone. Environ. Health Persp., 110: 660-661.

Thompson, C.A. and C. Vanderzant, 1976. Relationship of vibrio parahemlyticus in oysters, water and sediment, bacteriological and environmental indices. J. Food Sci., 41: 117-122.

Thornton, D.C.O., L.F. Dong, G.J.C. Underwood and D.B. Nedwell, 2002. Factors affecting microphytobenthic biomass, species composition and production in the Colne estuary (UK). Aquat. Microb. Ecol., 27: 285-300.

Underwood, G.J. and C. Kromkamp, 1999. Primary production by phytoplankton and microphytobenthos in estuaries. Adv. Ecol. Res., 29: 93-153.
Wan Norhana, N., A. Mohd-Nor-Azman and A.M. Ramlah, 2006. Comparison of faecal indicator bacterial counts in shellfish harvested from Kedah, Penang and Perak pre and post-tsunami. Malaysian J. Microbiol., 2: 35-39.

Wang, C.W., 1996. Assessment of microbial water quality of coastal waters in Southeast Asian countries. Penang, 11: 16-27.

Whitman, A.K., 2004. Finfish and shellfish bacteriology manual: Techniques and procedures. Wildlife Serv. Fish. Bull., 64: 1-4.

Wu, Q.L. and M.W. Hahn, 2006. Differences in structure and dynamics of Polynucleobacter communities in a temperate and a subtropical lake revealed at three phylogenetic levels. FEMS Microbiol. Ecol., 57: 67-79.

Yannarell, A.C. and E.W. Triplett, 2004. Within and between lake variability in the composition of bacterioplankton communities: Investigations using multiple spatial scales. Applied Environ. Microbiol., 70: 214-223. 